\title{
Preparation and electrochemical characterization of manganese dioxide-zirconia nanorods
}

\author{
R. R. Muthuchudarkodi • C. Vedhi
}

Received: 20 May 2014/ Accepted: 10 July 2014/Published online: 3 August 2014

(C) The Author(s) 2014. This article is published with open access at Springerlink.com

\begin{abstract}
MnO}_{2}-\mathrm{ZrO}_{2}$ nanorods were prepared by wet chemical method by mixing the solutions of $\mathrm{MnSO}_{4}$ and $\mathrm{ZrOCl}_{2}$ varying in the range $(0.05-0.45 \mathrm{M})$ in aqueous $\mathrm{NaOH}$ at an elevated temperature. The morphologies of the synthesized products are characterized by scanning electron microscopy and transmission electron microscopy (TEM). $\mathrm{X}$-ray diffraction (XRD) and energy-dispersive spectroscopic measurements were also employed for the characterization of the nanostructures. The synthesized nanoparticles were also characterized by ultraviolet visible spectroscopy, Fourier transform infrared spectroscopy, electrochemical impedance and cyclic voltammetric studies. The morphological studies of the nanoparticles revealed particle distribution with uniform rod-like structure. Energy-dispersive analysis indicated the presence of $\mathrm{Mn}, \mathrm{Zr}$ and $\mathrm{O}$. The nanostructures of the product were characterized by TEM studies and the mixed rod and granular structure that was found clearly indicated the presence of $\mathrm{MnO}_{2}-\mathrm{ZrO}_{2}$ mixed oxide. The size of the synthesized nanorod was found to be $20 \mathrm{~nm}$. From XRD studies the size of the nanorods was found to be in the range $39-56 \mathrm{~nm}$ calculated by Debye-Scherrer's formula. Thermal stability of the nanorods was characterized by thermogravimetric and differential scanning colorimetric analysis. Cyclic voltammetric studies exhibit good adherent behavior on electrode surface and good electroactivity at a $\mathrm{pH}$ value of 1.0 .
\end{abstract}

Keywords $\mathrm{MnO}_{2}-\mathrm{ZrO}_{2}$ nanorods $\cdot$ Impedance $\cdot \mathrm{SEM}$. TEM and cyclic voltammetry

R. R. Muthuchudarkodi · C. Vedhi ( $\square)$

Department of Chemistry, V.O Chidambaram College,

Tuticorin 628008, Tamilnadu, India

e-mail: cvedhi23@gmail.com; cvedhi@rediffmail.com

R. R. Muthuchudarkodi

e-mail: muthu.rajaram@gmail.com

\section{Introduction}

One-dimensional (1D) nanostructured materials, including nanotubes, nanorods, and nanowires, have attracted intense research interest, owing to their novel physical and chemical properties (Chen et al. 2005). Various methods have been developed to prepare various 1D nanomaterials, such as arc discharge, laser ablation, chemical vapor deposition, templating, and hydrothermal methods, etc. $\mathrm{MnO}_{2}$ is one of the most attractive materials due to its ion exchange, molecular adsorption, catalytic, electrochemical, and magnetic properties (Chen et al. 2005). They are widely used as catalysts (Chen et al. 2005; Brock et al. 1998; Shi et al. 2010) molecular-sieves, ion-sieves (Feng et al. 1999) and especially as electrode materials in $\mathrm{Li} /$ $\mathrm{MnO}_{2}$ batteries because of its energetic compatibility in a reversible lithium electrochemical system, eco-friendliness, and low cost. The properties of $\mathrm{MnO}_{2}$ depend not only on the manganese oxidation state, but also on the structure type of $\mathrm{MnO}_{2}$ crystal. Great effort has been made to prepare nanocrystalline $\mathrm{MnO}_{2}$ with different structures. Over the past few years, the synthesis of nanostructures with controllable size and shape has been increased attracting attention (Dong et al. 2006). Manganese compounds, such as various manganese oxides/oxyhydroxides have been noticed owing to their specialities. Manganese oxyhydroxides, $\mathrm{MnOOH}$, are of considerable importance in many technological applications, e.g., electrochemical reaction, battery and electrochromic application (Dong et al. 2006). $\mathrm{Mn}_{3} \mathrm{O}_{4}$ is known to be an active catalyst in several oxidations and reductions, and can be used as a catalyst for the oxidation of methane and carbon monoxide of the selective reduction of nitrobenzene (Dong et al. 2006). Nanorods have potential applications in nanodevices (Xia et al. 2003; Lu and Lieber 2006). Manganese 
oxides have a wide range of applications such as battery materials (Hosono et al. 2009), catalysts and sensors. At present, a tremendous amount of comprehensive investigations are under way into the unique applications of nanorods and nanotubes, because they provide a great opportunity to investigate the dependence of optical/electrical properties, thermal transport, and mechanical performance on the nano-scaled dimensionality and size (Wang 2000). Nanomaterials, especially nanorods have enhanced performances in many fields such as sensors (Dietl et al. 2000), solar cells (Yu 2009) catalysts and battery materials. Of the various non-noble metals or transition-metal oxides studied, $\mathrm{MnO}_{2}$ enjoys a place of pride because of its cost-effectiveness and eco-friendly nature. Beyond these advantageous properties, $\mathrm{MnO}_{2}$ is a very promising material in a neutral electrolyte system. In the case of pseudo capacitors, various noble and transitionmetal oxides such as $\mathrm{RuO}_{2}, \mathrm{IrO}_{2}, \mathrm{NiO}, \mathrm{CoOx}, \mathrm{SnO}_{2}$ and $\mathrm{MnO}_{2}$ were used as electrode materials (Subramanian et al. 2008). Zirconium dioxide is the most studied ceramic material. Pure $\mathrm{ZrO}_{2}$ has a monoclinic structure at room temperature and transitions to tetragonal and cubic at increasing temperature. Zirconia supports are of particular interest as they can possess relatively high surface areas; they are mechanically and thermally stable and are solids with adsorbent properties, as well as catalysts themselves. Wambach et al. (1999) have recently reviewed the preparation of metal-zirconia catalysts along with their structural and chemical characteristics. Stabilized zirconia is used in oxygen sensors, fuel cell membranes and electroceramics. It will be used as insulators in transistors in future nanoelectronic devices. In this study an attempt has been made to synthesize and characterize novel, mixed $\mathrm{MnO}_{2}-\mathrm{ZrO}_{2}$ nanorods.

\section{Experiment}

\section{Materials}

The precursors zirconiumoxychloride $\left(\mathrm{ZrOCl}_{2}\right)$, manganese sulfate $\left(\mathrm{MnSO}_{4}\right)$ and the precipitant $(\mathrm{NaOH})$ were purchased from Aldrich. All solutions were made up with deionised water.

Preparation of simple metal oxide nanoparticles

Fifty milliliters of $0.1 \mathrm{M} \mathrm{MnSO}_{4}$ was added dropwise to an aqueous solution of $\mathrm{NaOH}(50 \mathrm{ml}, 1.0 \mathrm{M})$, making a final volume of $100 \mathrm{ml}$. The mixture was stirred well and refluxed at an elevated temperature for $2.0 \mathrm{~h}$. The sample was collected by centrifugation, washed with water and dried over for 4 days at room temperature. Similar procedure was carried out for the preparation of $\mathrm{ZrO}_{2}$ nanoparticles using $\mathrm{ZrOCl}_{2}$ as the precursor.

Preparation of $\mathrm{MnO}_{2}-\mathrm{ZrO}_{2}$ nanorods

$\mathrm{MnO}_{2}-\mathrm{ZrO}_{2}$ nanorod was prepared by wet chemical method. In this method, $25 \mathrm{ml}$ of $0.45 \mathrm{M} \mathrm{ZrOCl}_{2}$ was added to the aqueous solution of $50 \mathrm{ml}$ of $1.0 \mathrm{M} \mathrm{NaOH}$ solution and stirred well. To this mixture, $25 \mathrm{ml}$ of $0.45 \mathrm{M}$ $\mathrm{MnSO}_{4}$ was added making a final volume of $100 \mathrm{ml}$. The resulting mixture was stirred well and refluxed at an elevated temperature for $2.0 \mathrm{~h}$. The sample was collected by centrifugation, washed with water and dried over for 4 days at room temperature. Similar procedure was carried out to prepare different concentrations of $(0.05-0.35 \mathrm{M})$ $\mathrm{MnO}_{2}-\mathrm{ZrO}_{2}$ mixed oxides.

\section{Characterizations}

The solution of the metal oxide nanoparticles in DMSO was used for recording the ultraviolet visible spectroscopic (UV-Vis) spectra. For recording the UV-Visible absorption spectra, a computer-controlled JascoV-500 spectrophotometer was used. The FTIR spectra were recorded using a Shimadzu instrument. The X-ray diffraction (XRD) patterns were recorded for the powdered materials using a Bruker AXS (D8 Advance) X-ray diffractometer. Energydispersive spectroscopic (EDAX) and SEM measurements were carried out by JEOL JSM-6360F field emission scanning electron microscope. Transmission electron microscopy (TEM) images were recorded using Philips CM 200 model with the operating voltage range 20-200 and with a resolution of $2.4 \AA$.

The electrochemical studies were carried out in a threeelectrode cell. Pt wire was used as a counter electrode, silver-silver chloride electrode as a reference electrode and metal oxide nanoparticle-coated GCE was used as working electrode. The impedance studies were carried out using electrochemical workstation (mode 650C), CH-Instrument Inc., TX, USA. The charge transfer resistance was obtained from the diameter of the semicircles of the Nyquist plots. TGA/DTA analysis was carried out using PerkinElmer model and DSC analysis using METTLER TOLEDO model.

\section{Result and discussion}

UV-Vis studies

Ultraviolet visible (UV-Vis) absorbtion spectra of nano $\mathrm{MnO}_{2}$, nano $\mathrm{ZrO}_{2}$ and mixed $\mathrm{MnO}_{2}-\mathrm{ZrO}_{2}$ were recorded in the range $200-800 \mathrm{~nm}$ as shown in (Fig. 1). The absorption 


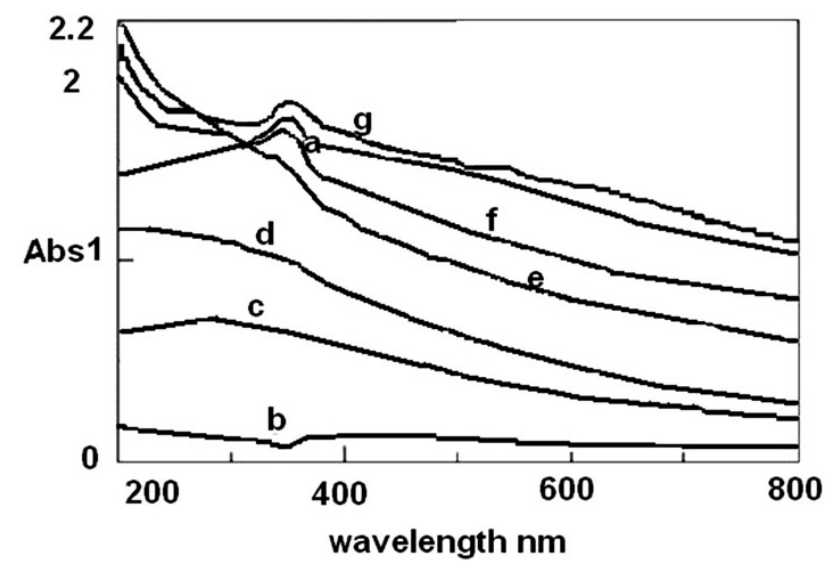

Fig. 1 UV-VIS spectra of ( $a$ ) nano $\mathrm{MnO}_{2}$, (b) nano $\mathrm{ZrO}_{2}$, (c) $0.05 \mathrm{M}$ $\mathrm{MnO}_{2}-\mathrm{ZrO}_{2}$, (d) $0.15 \mathrm{M} \mathrm{MnO}_{2}-\mathrm{ZrO}_{2}$, (e) $0.25 \mathrm{M} \mathrm{MnO}-\mathrm{ZrO}_{2}$, (f) $0.35 \mathrm{M} \mathrm{MnO}_{2}-\mathrm{ZrO}_{2},(g) 0.45 \mathrm{M} \mathrm{MnO}_{2}-\mathrm{ZrO}_{2}$ wavelength appears at $348 \mathrm{~nm}$ for nano $\mathrm{MnO}_{2}$ (Luo et al. 2004) and $335 \mathrm{~nm}$ for nano $\mathrm{ZrO}_{2}$. The absorption peaks for different concentrations $(0.05-0.45 \mathrm{M})$ of $\mathrm{MnO}_{2}-\mathrm{ZrO}_{2}$ mixed oxides have been found to be in the range 281-348 nm, and are shown in Fig. 1. The variations in the absorption peaks for simple and mixed oxides are due to the smaller size of the nanoparticles (Singh et al. 2012). The mixed oxide nanoparticles exhibited blue shift compared with that of the simple oxides. The blue shift of the absorption peaks of the metal oxide nanoparticles result from certain unique effects of nanomaterials such as nanoscale effect and the blue shift reduces absorption of longer wavelength and is thus undesirable for UV protection (Yang et al. 2004). The absorption peaks of metal oxide nanoparticles appeared at a shorter wavelength region. Thus the metal oxide nanoparticles are found to be
Fig. 2 FTIR Spectra of (a) nano $\mathrm{ZrO}_{2}$, b nano $\mathrm{MnO}_{2}$, c $0.05 \mathrm{M} \mathrm{MnO}_{2}-\mathrm{ZrO}_{2}$, d $0.15 \mathrm{M}$ $\mathrm{MnO}_{2}-\mathrm{ZrO}_{2}$, e $0.25 \mathrm{M} \mathrm{MnO}_{2}-$ $\mathrm{ZrO}_{2}$, f $0.35 \mathrm{M} \mathrm{MnO}_{2}-\mathrm{ZrO}_{2}$, g $0.45 \mathrm{M} \mathrm{MnO}_{2}-\mathrm{ZrO}_{2}$

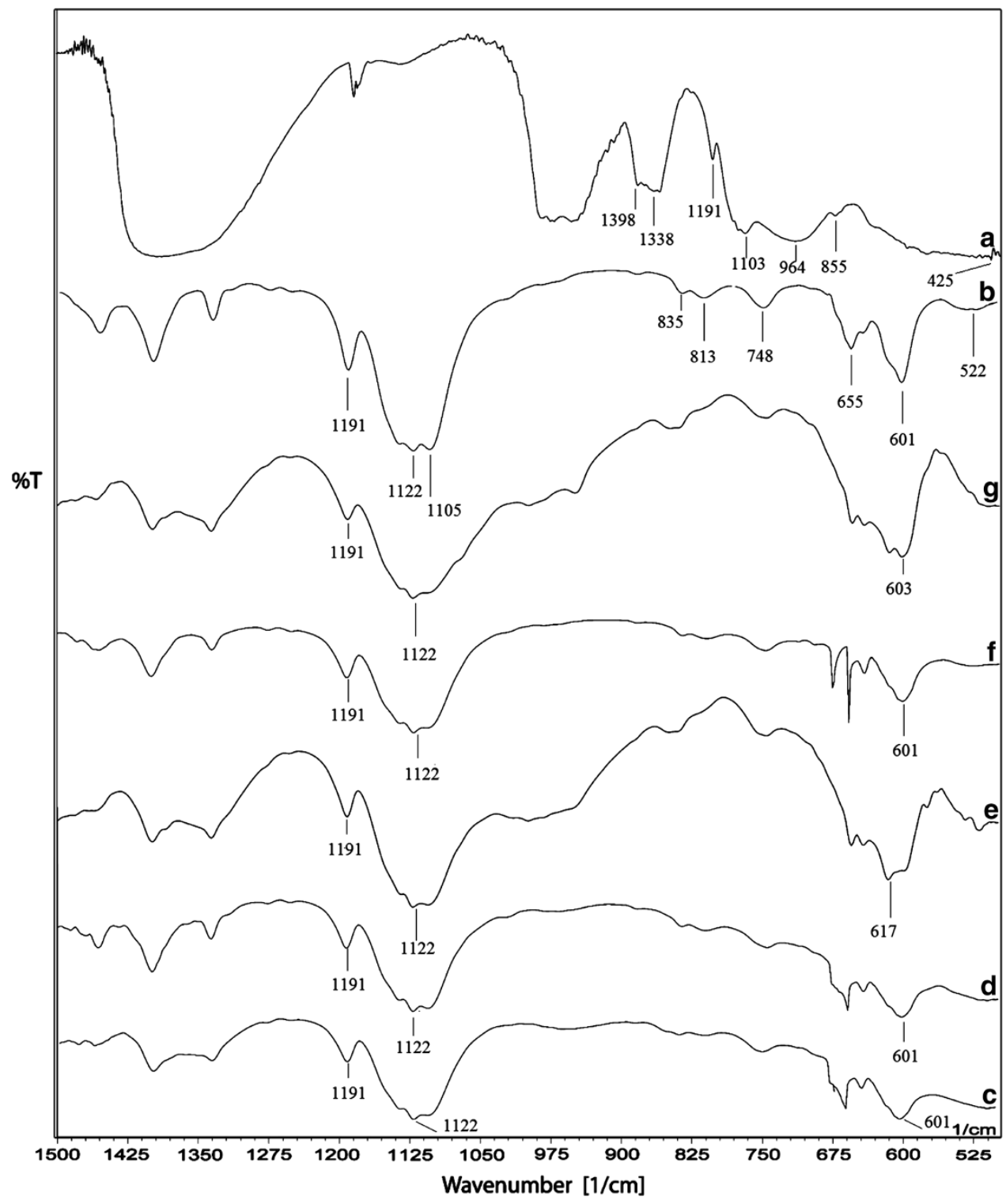


solar UV blockers (Yang et al. 2004). With the increase in concentrations of nano $\mathrm{MnO}_{2}-\mathrm{ZrO}_{2}$ mixed oxides there appeared increase in absorption values.

\section{FTIR studies}

Metal oxides generally give absorption bands below $1,000 \mathrm{~cm}^{-1}$ that arise from interatomic vibrations given in Fig. 2. The frequencies observed at 511-954 and $425-964 \mathrm{~cm}^{-1}$ correspond to Mn-O (Rema Devi et al. 2007) and $\mathrm{Zr}-\mathrm{O}$ (Ṕerez-Maquedaa and Matijevicb 1997) bond vibrations, respectively. The peaks observed at 1,336 and $1,338 \mathrm{~cm}^{-1}$ are assigned to $\mathrm{O}_{2}$ stretching frequency (Guedes et al. 2009). Symmetric frequencies of $\mathrm{Mn}-\mathrm{O}$ and $\mathrm{Zr}-\mathrm{O}$ were observed at 1,191 and 1,103 $\mathrm{cm}^{-1}$ (Guedes et al. 2009; Du et al. 2009). The peak observed at $3,401 \mathrm{~cm}^{-1}$ corresponds to $\mathrm{O}-\mathrm{H}$ vibration of water. The characteristic peaks observed at 1,122 and $1,103 \mathrm{~cm}^{-1}$ are due to the presence of inorganic ions (Rema Devi et al. 2007).

Fourier transform infrared spectroscopic (FTIR) spectra of $\mathrm{MnO}_{2}-\mathrm{ZrO}_{2}$ mixed oxides synthesized at five different concentrations of both $\mathrm{MnSO}_{4}$ and $\mathrm{ZrOCl}_{2}(0.05,0.15$, $0.25,0.35$ and 0.45 ) are shown in Fig. 2c-g. For mixed oxide nanorods $(0.45 \mathrm{M}) \mathrm{MnO}_{2}-\mathrm{ZrO}_{2}$, the combination of both $\mathrm{Mn}-\mathrm{O}$ and $\mathrm{Zr}-\mathrm{O}$ bonds appear in the range $511-999 \mathrm{~cm}^{-1}$ Fig. $2 \mathrm{~g}$. The frequencies observed at 1,336 and $1,396 \mathrm{~cm}^{-1}$ are assigned to $\mathrm{O}_{2}$ stretching and bending frequencies, respectively (Partha Sarathi and Thilagavathi 2011). The characteristic peak at $1,122 \mathrm{~cm}^{-1}$ clearly indicates the presence of inorganic ions (Du et al. 2009). In the case of other concentrations of $(0.05-0.35 \mathrm{M}) \mathrm{MnO}_{2}$ $\mathrm{ZrO}_{2}$ mixed oxides, the bands were almost similar to $0.45 \mathrm{M} \mathrm{MnO}_{2}-\mathrm{ZrO}_{2}$.

SEM and EDAX behaviors of nano $\mathrm{MnO}_{2}$, nano $\mathrm{ZrO}_{2}$ and $\mathrm{MnO}_{2}-\mathrm{ZrO}_{2}$

Scanning electron microscopy (SEM) was used to identify the morphology of the synthesized metal oxides and mixed metal oxides $\mathrm{MnO}_{2}, \mathrm{ZrO}_{2}$ and $\mathrm{MnO}_{2}-\mathrm{ZrO}_{2}$. From Fig. 3a, $\mathrm{b}$ the prepared $\mathrm{MnO}_{2}$ and $\mathrm{ZrO}_{2}$ display sponge-like structure, granular flakes and mixed granular appearance. When $\mathrm{MnSO}_{4}$ and $\mathrm{ZrOCl}_{2}$ were mixed, the surface morphologies and roughness of the particles are changed to rod-like structure and become homogeneous which confirmed the formation of $\mathrm{MnO}_{2}-\mathrm{ZrO}_{2}$ nanoparticles. SEM micrographs of nano $\mathrm{MnO}_{2}-\mathrm{ZrO}_{2}$ synthesized at five different concentrations of both $\mathrm{MnSO}_{4}$ and $\mathrm{ZrOCl}_{2}(0.05,0.15,0.25,0.35$, and 0.45 ) are shown in Fig. 3c-g. Particles synthesized in $0.05 \mathrm{M}$ of $\mathrm{MnSO}_{4}$ and $\mathrm{ZrOCl}_{2}$ appear to be very uniform in spherical morphology. In the case of $0.15 \mathrm{M}$ of $\mathrm{MnSO}_{4}$ and $\mathrm{ZrOCl}_{2}$ and $0.25 \mathrm{M}$ of $\mathrm{MnSO}_{4}$ and $\mathrm{ZrOCl}_{2}$, the particles were modified from spherical into rod-like morphology.
However, the nano $\mathrm{MnO}_{2}-\mathrm{ZrO}_{2}$ mixed oxides synthesized in the $0.35 \mathrm{M}$ of $\mathrm{MnSO}_{4}$ and $\mathrm{ZrOCl}_{2} ; 0.45 \mathrm{M}$ of $\mathrm{MnSO}_{4}$ and $\mathrm{ZrOCl}_{2}$ were completely changed into nanorods. By choosing the adequate concentration we would be able to form nanorods. EDAX analysis confirms the presence of $\mathrm{Mn}, \mathrm{Zr}$ and $\mathrm{O}$ as shown in Fig. 3.

TEM behaviors of nano $\mathrm{MnO}_{2}$, nano $\mathrm{ZrO}_{2}$ and $\mathrm{MnO}_{2}-$ $\mathrm{ZrO}_{2}$

Transmission electron microscopy (TEM)'s image of $\mathrm{MnO}_{2}$ nanoparticles shows the size of the nanoparticles to be $20 \mathrm{~nm}$ and Fig. 4a shows the size of the $\mathrm{ZrO}_{2}$ nanoparticles to be $100 \mathrm{~nm}$. The morphology of the synthesized nano $\mathrm{ZrO} 2$ also appeared rod-like and that of nano $\mathrm{MnO} 2$, sphere-like (Fig. 4b). The morphology of mixed nano metal oxide $\left(0.45 \mathrm{M}\right.$ of $\left.\mathrm{MnO}_{2}-\mathrm{ZrO}_{2}\right)$ was found to be a uniform rod and the size is observed to be $20 \mathrm{~nm}$ as shown in Fig. 4c.

XRD behaviors of nano $\mathrm{MnO}_{2}$, nano $\mathrm{ZrO}_{2}$ and $\mathrm{MnO}_{2}-$ $\mathrm{ZrO}_{2}$

The X-ray powder diffraction patterns for the simple and mixed oxide nanoparticles as in Fig. 5 are typical of crystalline nanoparticles. The particle size was calculated using Scherrer's equation. In the case of nano $\mathrm{MnO}_{2}$ the particle size was $45 \mathrm{~nm}$ and in the case of nano $\mathrm{ZrO}_{2}$ the particle size was $8.3 \mathrm{~nm}$. The average crystallite sizes of nanorods, $\mathrm{MnO}_{2}-\mathrm{ZrO}_{2}$ is found to be in the range of $39-56 \mathrm{~nm}$. With the increase in concentrations of $\mathrm{MnO}_{2}$ $\mathrm{ZrO}_{2}$ from 0.05 to $0.45 \mathrm{M}$ there is corresponding increase in size. The sharp peaks indicate more crystallinity and hence it shows more conductivity because high crystallinity materials usually show higher conductivity.

\section{Thermal analysis}

Figure 6 shows the thermograms of nano $\mathrm{ZrO}_{2}$, nano $\mathrm{MnO}_{2}$ and different concentrations of mixed $\mathrm{MnO}_{2}-\mathrm{ZrO}_{2}$ oxides. Figure 6a shows the TGA/DTA behavior of $\mathrm{MnO}_{2}$. The first weight loss step from 42 to $90{ }^{\circ} \mathrm{C}$ corresponds to loss of moisture. The next step from 91 to $580{ }^{\circ} \mathrm{C}$ was due to the presence of extra bounded water molecules. The final weight loss step from $581{ }^{\circ} \mathrm{C}$ onwards corresponds to the degradation of $\mathrm{MnO}_{2}$. The first weight loss step from 30 to $100{ }^{\circ} \mathrm{C}$ (Fig. 6b) corresponds to loss of moisture. The next step from 101 to $170{ }^{\circ} \mathrm{C}$ was due to the presence of extra bounded water molecules. The final weight loss step from $170{ }^{\circ} \mathrm{C}$ onwards corresponds to the degradation of $\mathrm{ZrO}_{2}$. The DTA analysis also exhibited the same behavior.

Thermal stability of nano $\mathrm{MnO}_{2}-\mathrm{ZrO}_{2}$ mixed oxides synthesized at five different concentrations of both $\mathrm{MnSO}_{4}$ 
a

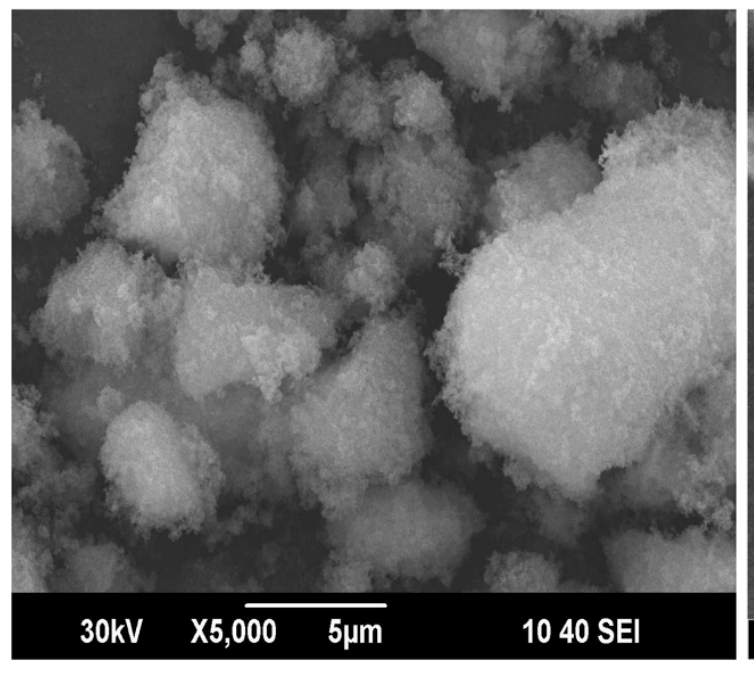

C

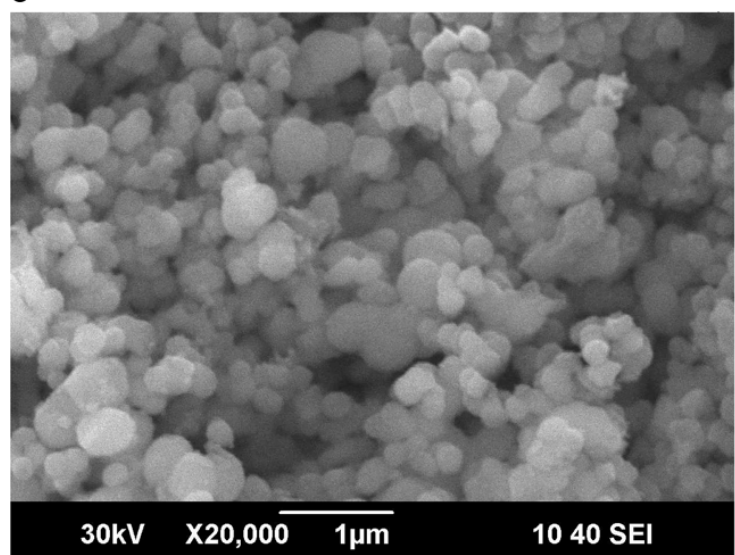

d

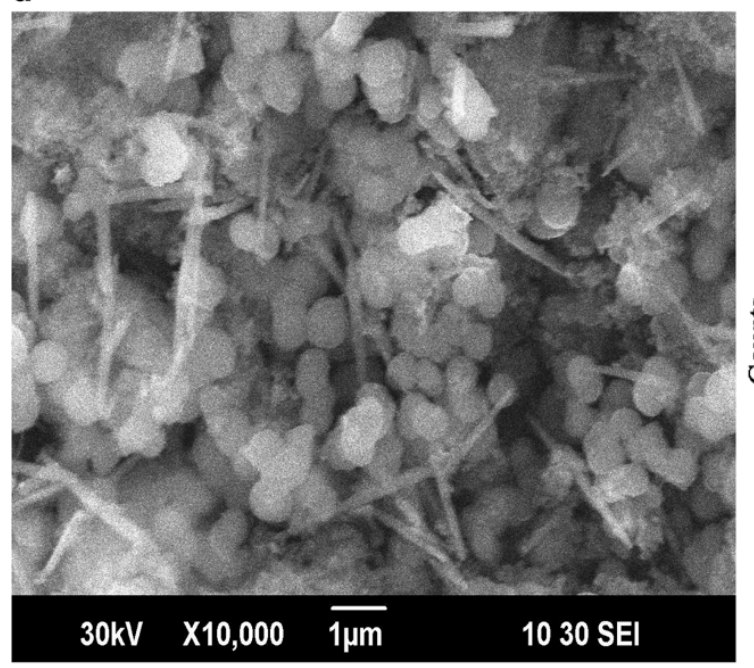

b
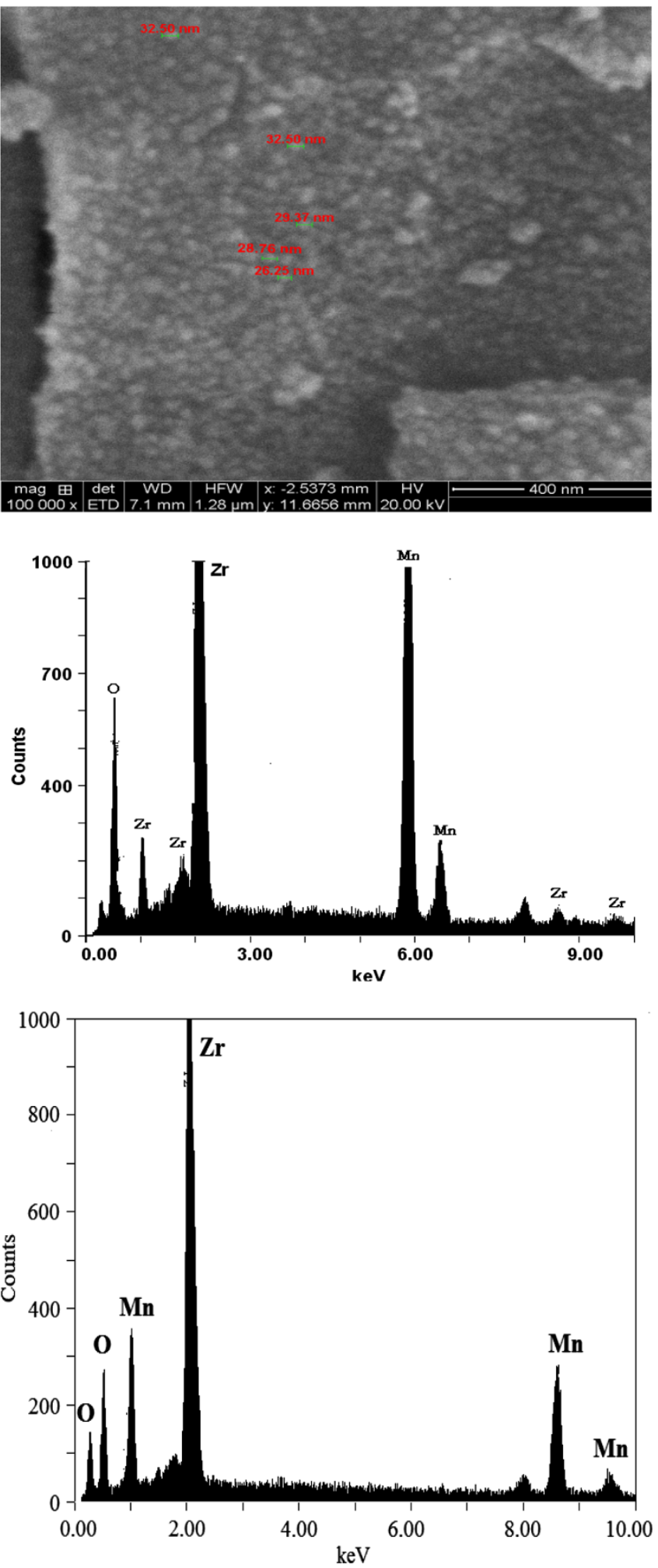

Fig. 3 SEM behavior of (a) nano $\mathrm{MnO}_{2}$, b nano $\mathrm{ZrO}_{2}$ and SEM image EDAX pattern of (c) $\mathrm{MnO}_{2}-\mathrm{ZrO}_{2}, \mathbf{d} \mathrm{MnO}_{2}-\mathrm{ZrO}_{2}$, e $\mathrm{MnO}_{2}-\mathrm{ZrO}_{2}$, f $\mathrm{MnO}_{2}-\mathrm{ZrO}_{2}$, g $0.45 \mathrm{M} \mathrm{MnO}{ }_{2}-\mathrm{ZrO}_{2}$ 


\section{e}
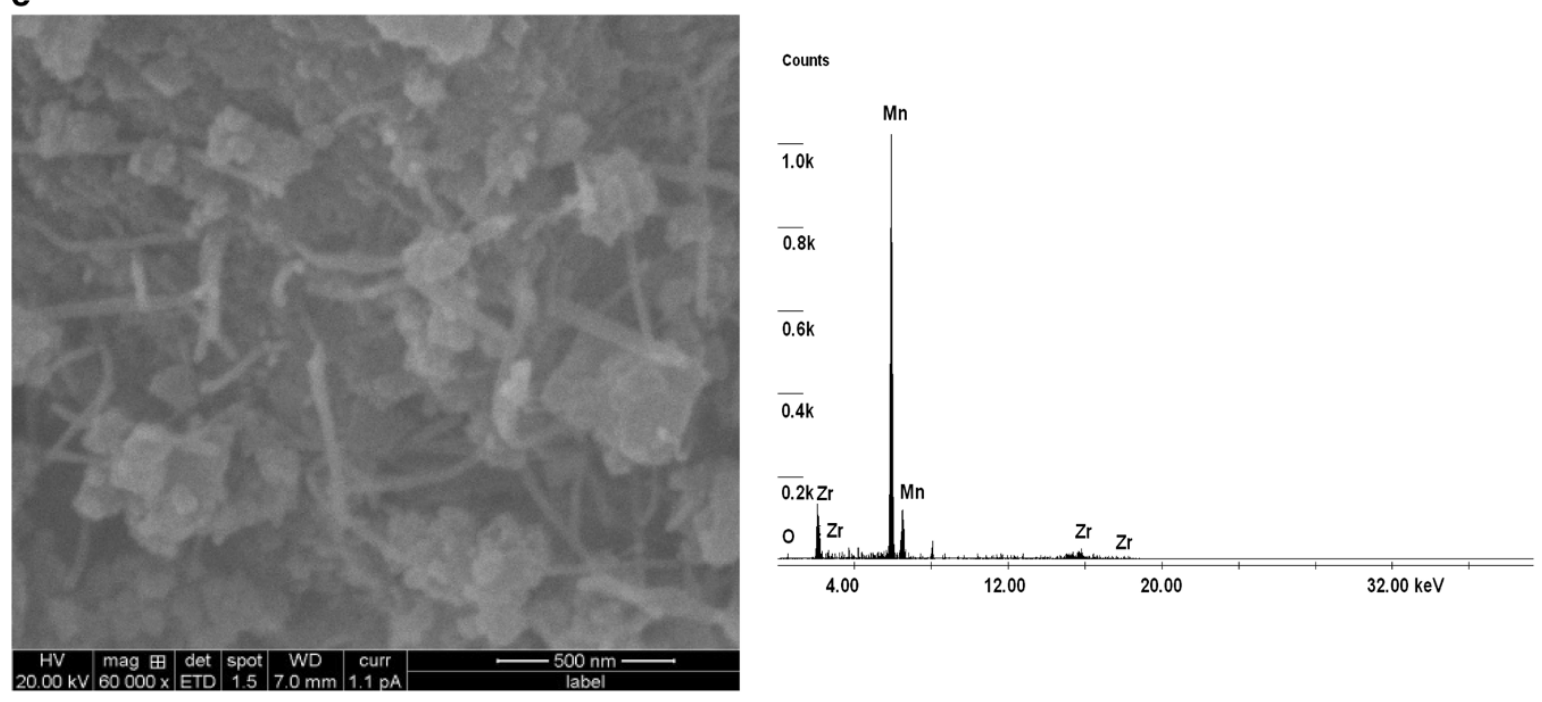

$\mathbf{f}$
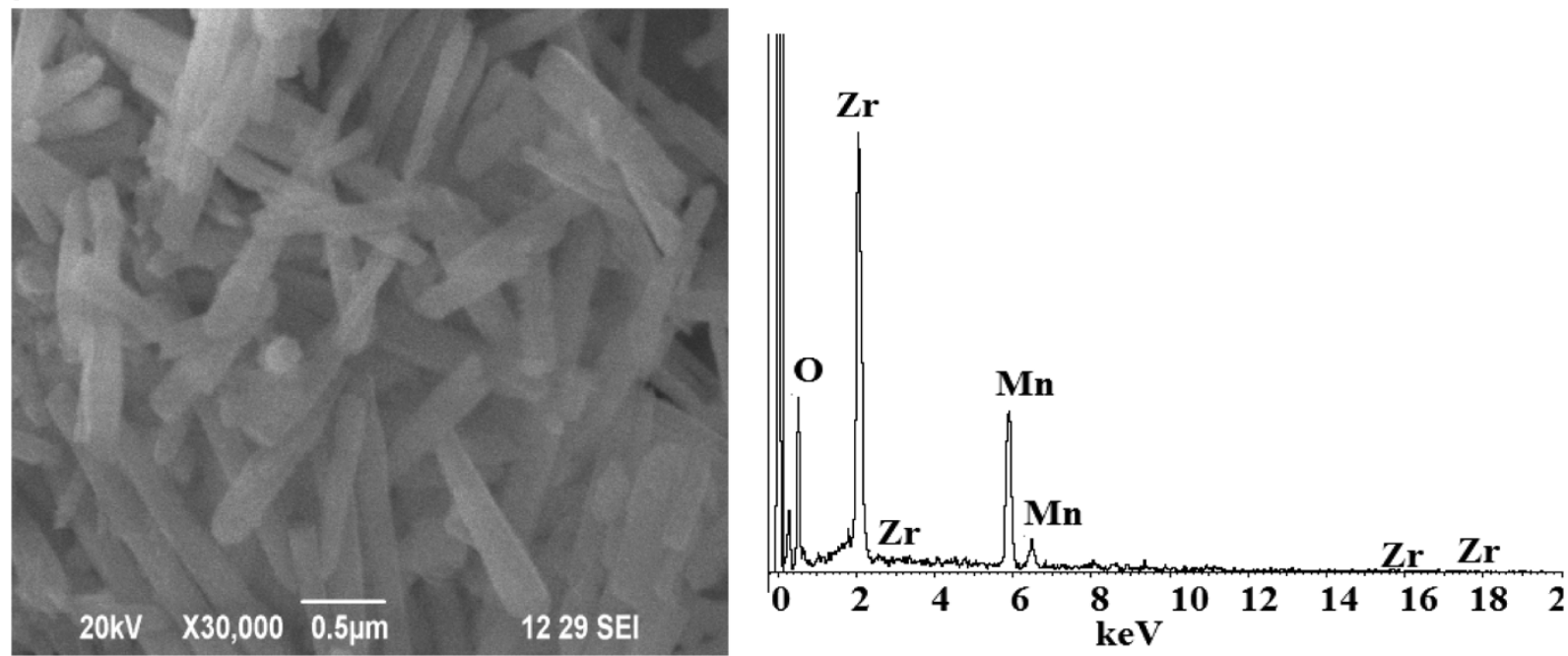

g
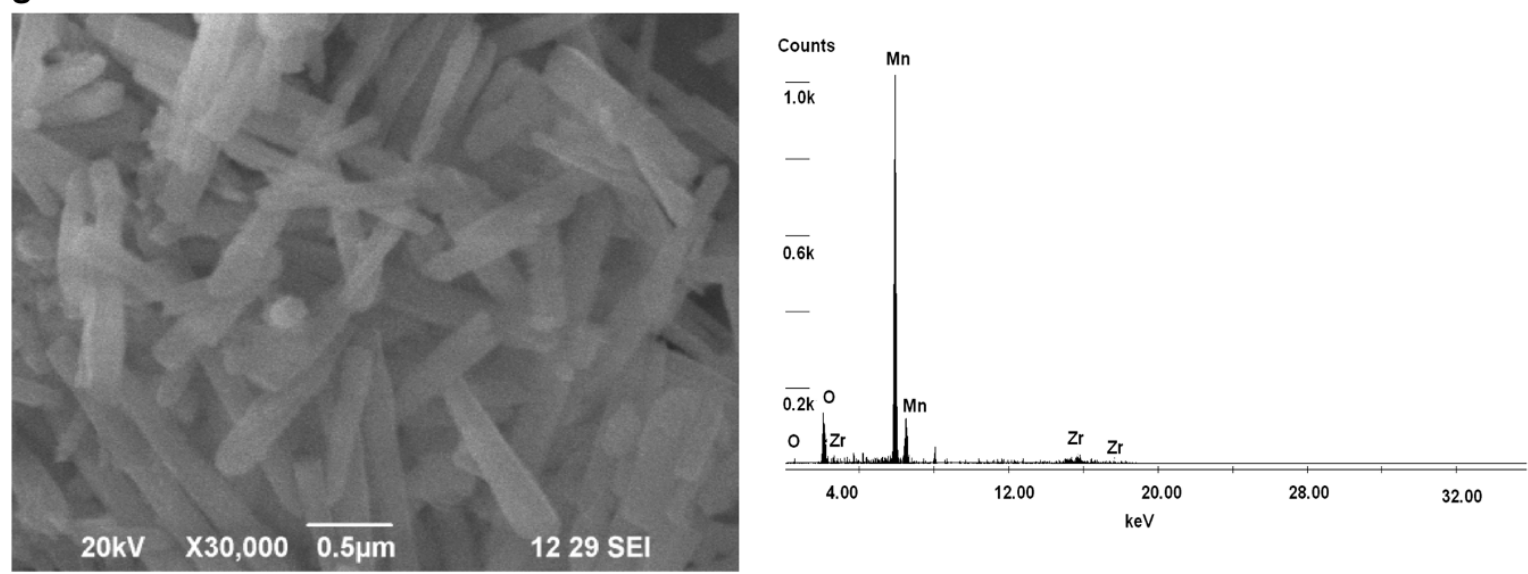

Fig. 3 continued

and $\mathrm{ZrOCl}_{2}(0.05,0.15,0.25,0.35,0.45 \mathrm{M})$ is characterized by TGA/DTA analysis and the results are shown in Table 1. In these curves the first weight loss step from 42 to
$170{ }^{\circ} \mathrm{C}$ corresponds to the loss of moisture. The next weight loss step from 91 to $390{ }^{\circ} \mathrm{C}$ corresponds to extra bounded water molecules. The final weight loss step from 

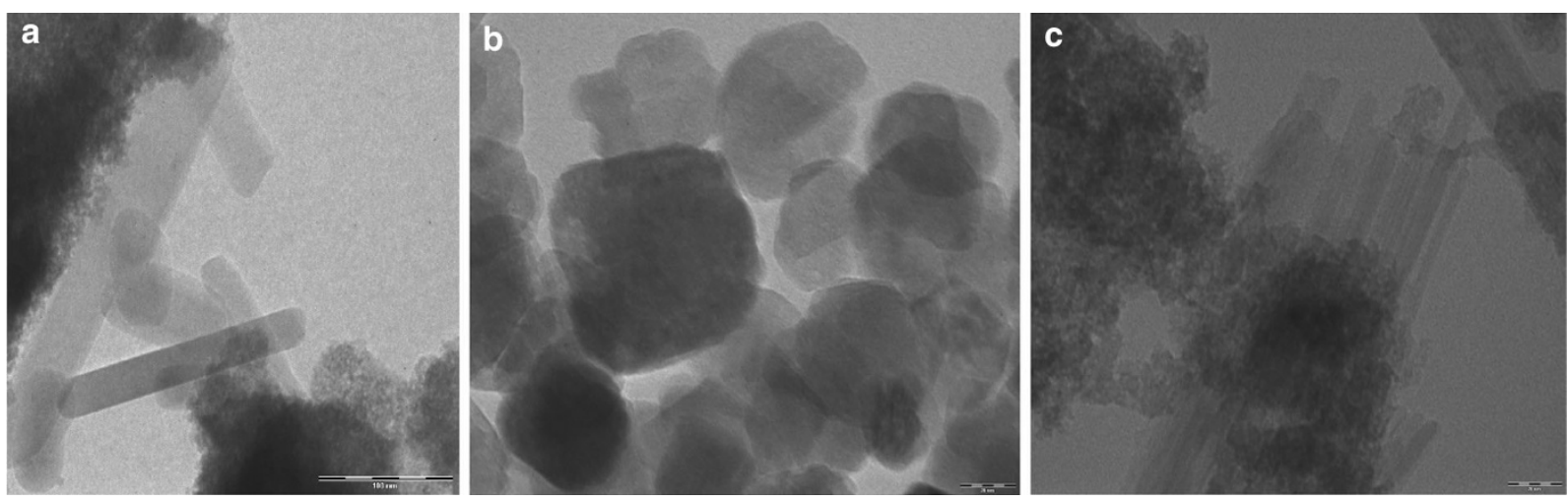

Fig. 4 TEM image of (a) nano $\mathrm{ZrO}_{2}, \mathbf{b} \mathrm{MnO}_{2}$ nanoparticles, $\mathbf{c} \mathrm{MnO}_{2}-\mathrm{ZrO}_{2}(0.45 \mathrm{M})$ nanorod

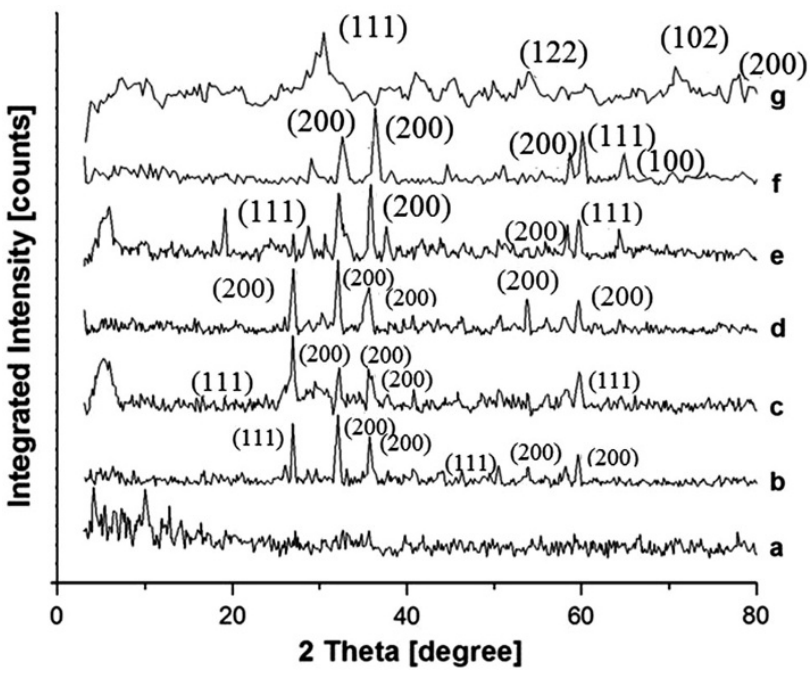

Fig. 5 XRD Pattern of (a) nano $0.05 \mathrm{M} \mathrm{MnO}_{2}-\mathrm{ZrO}_{2}$, (b) $0.15 \mathrm{M}$ $\mathrm{MnO}_{2}-\mathrm{ZrO}_{2}$, (c) $\mathrm{MnO}_{2}-\mathrm{ZrO}_{2}$, (d) $\mathrm{MnO}_{2}-\mathrm{ZrO}_{2}$, (e) $\mathrm{MnO}_{2}-\mathrm{ZrO}_{2}$, (f) nano $\mathrm{MnO}_{2}$, (g) nano $\mathrm{ZrO}_{2}$

281 to $321{ }^{\circ} \mathrm{C}$ corresponds to the degradation of mixed oxides $\left(\mathrm{MnO}_{2}-\mathrm{ZrO}_{2}\right)$. The weight loss values at the critical temperatures such as $280,300,320$ and $390{ }^{\circ} \mathrm{C}$ reveal that the type of simple oxides employed affects the thermal properties of the resulting mixed oxides. The thermogram of $0.05 \mathrm{M} \mathrm{MnO}_{2}-\mathrm{ZrO}_{2}$ is shown in Fig. 6c.

DSC thermogram of $\mathrm{MnO}_{2}, \mathrm{ZrO}_{2}$ and different concentrations of mixed $\mathrm{MnO}_{2}-\mathrm{ZrO}_{2}$ are recorded at the heating rate $10{ }^{\circ} \mathrm{C} \mathrm{min}^{-1}$. The glass transition temperature $\left(T_{\mathrm{g}}\right)$ crystallization temperature $\left(T_{\mathrm{C}}\right)$ and melting point $\left(T_{\mathrm{M}}\right)$ of the mixed oxide are determined from the DSC curves (Fig. 7a) shows the melting point $\left(T_{\mathrm{M}}\right)$ of $\mathrm{MnO}_{2}$ at a temperature of $237{ }^{\circ} \mathrm{C}$ and the $\left(T_{\mathrm{C}}\right)$ value at $220^{\circ} \mathrm{C}$. The melting point $\left(T_{\mathrm{M}}\right)$ of $\mathrm{ZrO}_{2}$ was recorded at a temperature of $95{ }^{\circ} \mathrm{C}$, the $T_{\mathrm{C}}$ value recorded at $10{ }^{\circ} \mathrm{C}$ and the $T_{\mathrm{g}}$ value recorded at $-70{ }^{\circ} \mathrm{C}$. These results can be seen in Fig. $7 \mathrm{~b}$. The $T_{\mathrm{C}}$ value of $\mathrm{MnO}_{2}-\mathrm{ZrO}_{2}$ mixed oxide is in the range of
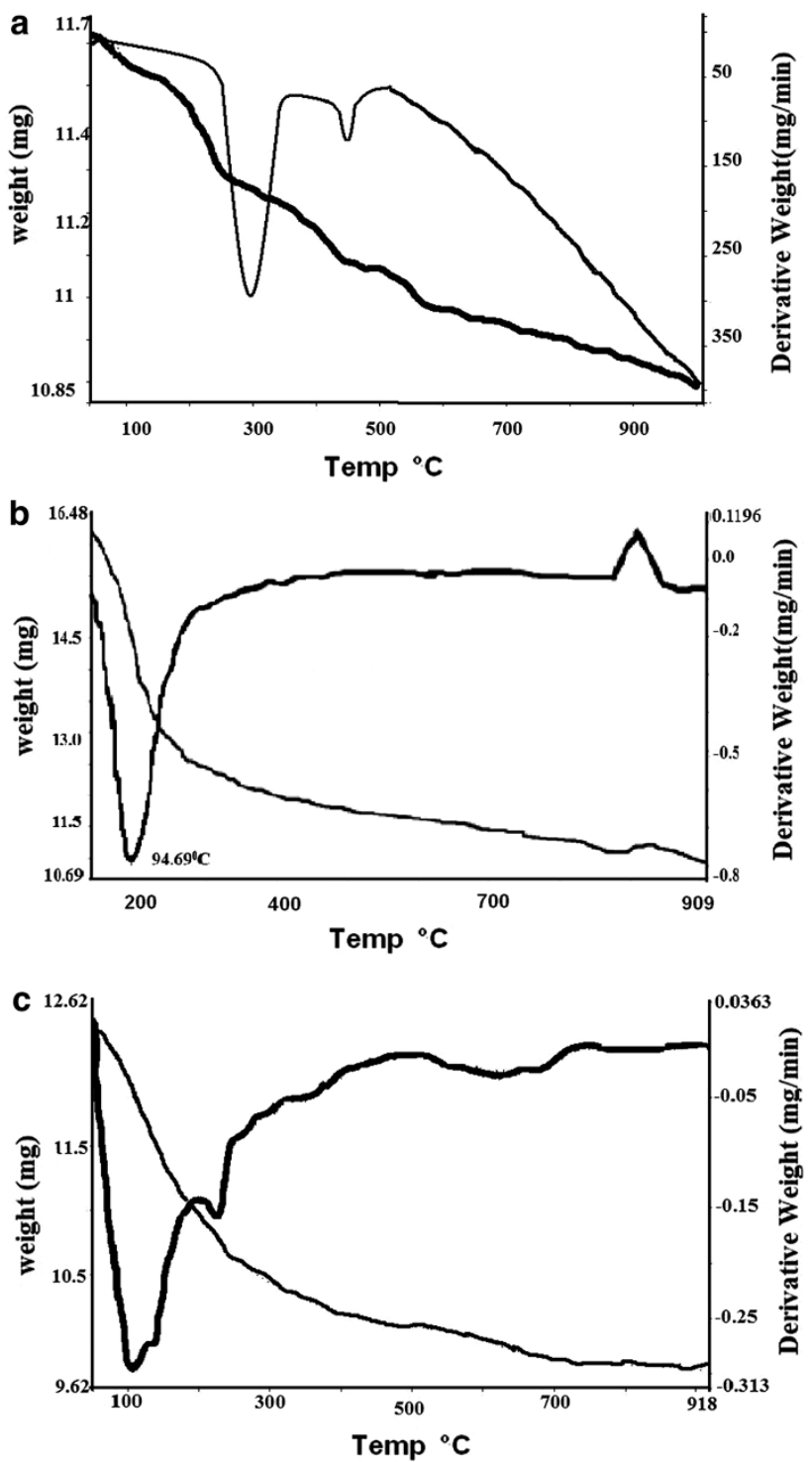

Fig. 6 TGA/DTA Curves of (a) nano $\mathrm{MnO}_{2}$, b nano $\mathrm{ZrO}_{2}$, c $0.05 \mathrm{M}$ $\mathrm{MnO}_{2}-\mathrm{ZrO}_{2}$ 
Table 1 TGA analysis of nano $\mathrm{ZrO}_{2}$, nano $\mathrm{MnO}_{2}$ and $\mathrm{MnO}_{2}-\mathrm{ZrO}_{2}$ mixed oxides

\begin{tabular}{|c|c|c|c|}
\hline Nanoparticles & $\begin{array}{l}\text { Temperature } \\
\text { due to loss of } \\
\text { moisture }\left({ }^{\circ} \mathrm{C}\right)\end{array}$ & $\begin{array}{l}\text { Temperature } \\
\text { due to loss of } \\
\text { water }\left({ }^{\circ} \mathrm{C}\right)\end{array}$ & $\begin{array}{l}\text { Temperature due to } \\
\text { degradation of } \\
\text { mixed oxides }\left({ }^{\circ} \mathrm{C}\right)\end{array}$ \\
\hline $\mathrm{ZrO}_{2}$ & $30-100$ & $101-170$ & From 171 onwards \\
\hline $\mathrm{MnO}_{2}$ & $42-90$ & $91-580$ & From 581 onwards \\
\hline $\begin{array}{l}0.05 \mathrm{M} \\
\mathrm{MnO}_{2-} \\
\mathrm{ZrO}_{2}\end{array}$ & $55-170$ & $171-390$ & From 391 onwards \\
\hline $\begin{array}{l}0.15 \mathrm{M} \\
\mathrm{MnO}_{2-} \\
\mathrm{ZrO}_{2}\end{array}$ & $42-100$ & $101-320$ & From 321 onwards \\
\hline $\begin{array}{l}0.25 \mathrm{M} \\
\mathrm{MnO}_{2-} \\
\mathrm{ZrO}_{2}\end{array}$ & $45-180$ & $181-320$ & From 321 onwards \\
\hline $\begin{array}{l}0.35 \mathrm{M} \\
\mathrm{MnO}_{2-} \\
\mathrm{ZrO}_{2}\end{array}$ & $42-90$ & $91-300$ & From 301 onwards \\
\hline $\begin{array}{c}0.45 \mathrm{M} \\
\mathrm{MnO}_{2-} \\
\mathrm{ZrO}_{2}\end{array}$ & $45-120$ & $121-280$ & From 281 onwards \\
\hline
\end{tabular}

29.93-36.35 ${ }^{\circ} \mathrm{C}$. The mixed oxide was melted at the temperature range of $76.24-93.11^{\circ} \mathrm{C}$. According to DSC the melting temperature $T_{\mathrm{M}}$ of different concentrations of mixed oxide was decreased remarkably than the simple oxides. Table 2 shows the $T_{\mathrm{C}}$ and $T_{\mathrm{M}}$ values of $0.05-0.45 \mathrm{M} \mathrm{MnO}_{2}-\mathrm{ZrO}_{2}$ mixed oxides. DSC thermogram of $0.05 \mathrm{M} \mathrm{MnO}_{2}-\mathrm{ZrO}_{2}$ and is shown in Fig. $7 \mathrm{c}$.

Cyclic voltammetric behavior of nano $\mathrm{MnO}_{2}$, nano $\mathrm{ZrO}_{2}$ and $\mathrm{MnO}_{2}-\mathrm{ZrO}_{2}$

Cyclic voltammetric studies of $\mathrm{ZrO}_{2}$ exhibited one oxidation peak at $0.179 \mathrm{~V}$ with higher peak current at $\mathrm{pH} 1.0$ which led to the selection of $\mathrm{pH}$ at 1.0 as optimum $\mathrm{pH}$ for further voltammetric studies. Cyclic voltammetric behavior of $\mathrm{MnO}_{2}$ showed one anodic peak (Fig. 8a) at $0.415 \mathrm{~V}$ which is due to the presence of $\mathrm{MnO}_{2}$ and it is reduced at $0.352 \mathrm{~V}$. Cyclic voltammetric behavior of $\mathrm{ZrO}_{2}$ showed one oxidation peak (Fig. 8b) observed at $0.179 \mathrm{~V}$, which indicated the formation of $\mathrm{ZrO}_{2}$, whereas for different concentrations of mixed oxides, two oxidation peaks were observed in the range $0.127-0.3238,0.6,535-0.6571 \mathrm{~V}$ (Fig. 9), respectively, which were entirely different from the behavior, those obtained from nano $\mathrm{MnO}_{2}$ and nano $\mathrm{ZrO}_{2}$, confirmed the formation of mixed nano $\mathrm{MnO}_{2}$ $\mathrm{ZrO}_{2}$ oxide. Cyclic voltammetric behavior of nano $\mathrm{MnO}_{2-}$ $\mathrm{ZrO}_{2}$ mixed oxides synthesized at five different concentrations of both $\mathrm{MnSO}_{4}$ and $\mathrm{ZrOCl}_{2}(0.05,0.15,0.25$, $0.35,0.45 \mathrm{M})$ are shown in Fig. 9a-e. With the increase in concentrations $(0.05-0.45 \mathrm{M})$ of nano $\mathrm{MnO}_{2}-\mathrm{ZrO}_{2}$
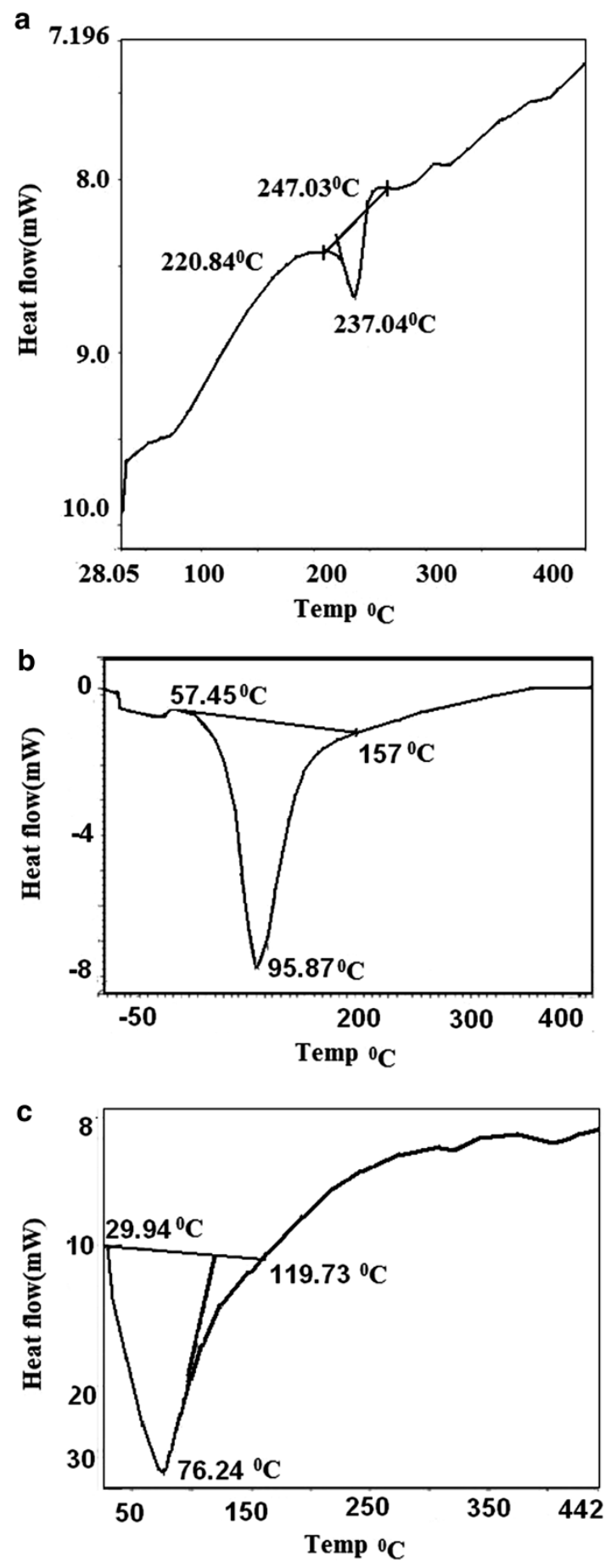

Fig. 7 DSC Thermograms of (a) nano $\mathrm{MnO}_{2}$, b nano $\mathrm{ZrO}_{2}$, c $0.05 \mathrm{M}$ $\mathrm{MnO}_{2}-\mathrm{ZrO}_{2}$

there is corresponding increase in peak potentials and peak currents also.

The plot of peak current versus different scan rate for nano $\mathrm{MnO}_{2}-\mathrm{ZrO}_{2}$ mixed oxide exhibits a straight line (Fig. 10) indicating a good adherent behavior on electrode surface. When peak currents of nano $\mathrm{MnO}_{2}-\mathrm{ZrO}_{2}$ are correlated with the square root of scan rate, a straight line is 
Table $2 T_{\mathrm{C}}$ and $T_{\mathrm{M}}$ for $0.05-0.45 \mathrm{M} \mathrm{MnO}_{2}-\mathrm{ZrO}_{2}$ mixed oxides

\begin{tabular}{lll}
\hline Concentration of $\mathrm{MnO}_{2}-\mathrm{ZrO}_{2}$ nanoparticles $(\mathrm{M})$ & $T_{\mathrm{C}}{ }^{\circ} \mathrm{C}$ & $T_{\mathrm{M}}{ }^{\circ} \mathrm{C}$ \\
\hline 0.05 & 29.94 & 76.24 \\
0.15 & 36.35 & 77.20 \\
0.25 & 32.60 & 81.90 \\
0.35 & 29.93 & 82.41 \\
0.45 & 34.59 & 93.11
\end{tabular}

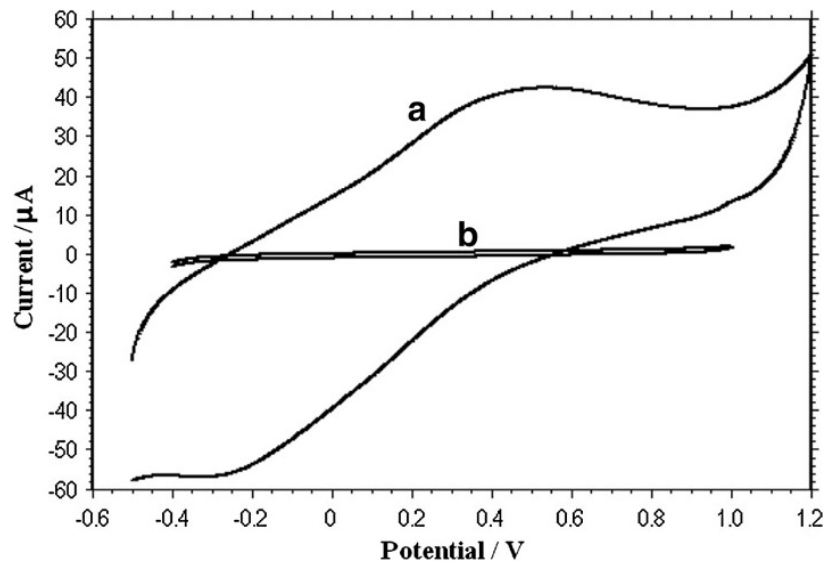

Fig. 8 Cyclic Voltammetric behavior of (a) nano $\mathrm{MnO}_{2}$, b nano $\mathrm{ZrO}_{2}$

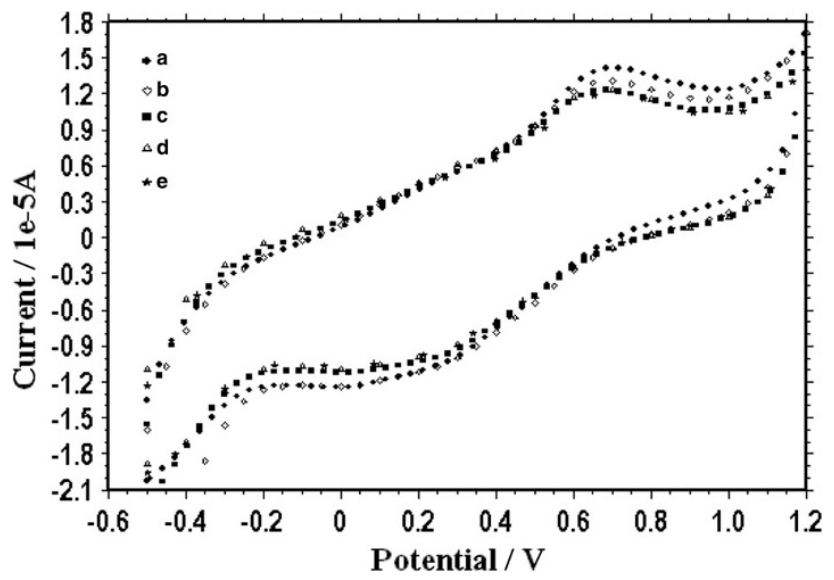

Fig. 9 Cyclic voltammetric behavior of (a) $0.05 \mathrm{M}$ nano $\mathrm{MnO}_{2}-$ $\mathrm{ZrO}_{2}$, b $0.15 \mathrm{M} \mathrm{MnO} \mathrm{MrO}_{2}$, c $0.25 \mathrm{M} \mathrm{MnO}_{2}-\mathrm{ZrO}_{2}$, d $0.35 \mathrm{M}$ $\mathrm{MnO}_{2}-\mathrm{ZrO}_{2}$, e $0.45 \mathrm{M} \mathrm{MnO}_{2}-\mathrm{ZrO}_{2}$

observed (Fig. 11). These facts reveal that the voltammetric redox behavior of mixed metal oxide nanoparticles is controlled by adsorption process. Thus it proves to be an anticorrosive agent for paints.

When the metal salts of $\mathrm{Mn}$ and $\mathrm{Zr}$ were mixed during chemical co-precipitation, the mixed metal oxide nanoparticles were produced. The mixed metal oxide was coated on glassy carbon electrode and the cyclic voltammogram was recorded. The voltammogram also exhibited oxidation and reduction peaks with higher peak current.

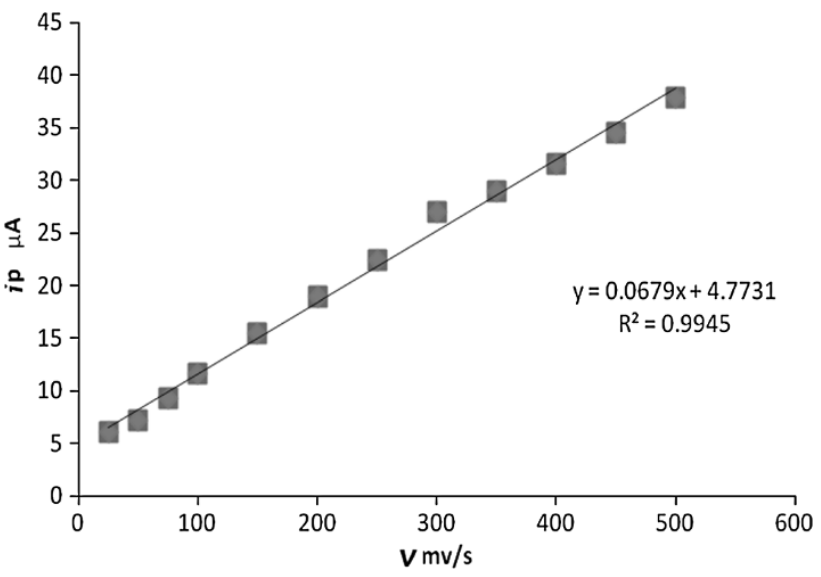

Fig. 10 Plot of peak current versus scan rate for $0.45 \mathrm{M}$ nano $\mathrm{MnO}_{2}-$ $\mathrm{ZrO}_{2}$

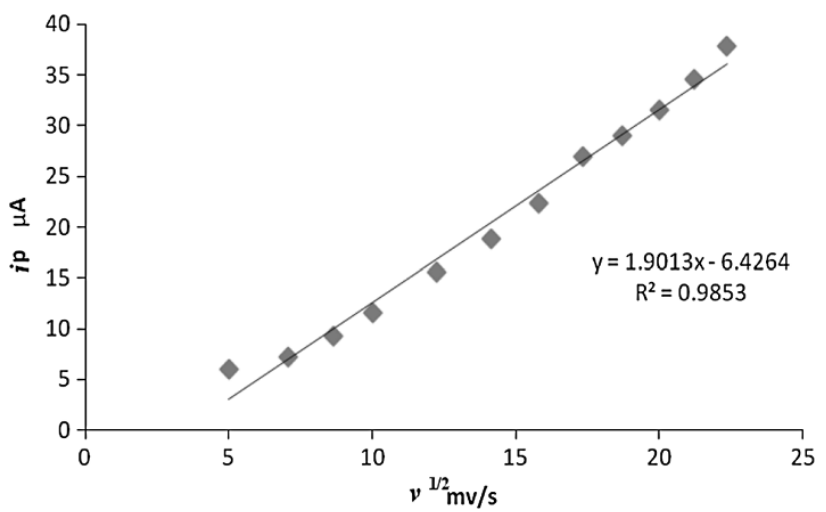

Fig. 11 Plot of peak current versus square root of scan rate for $0.45 \mathrm{M}$ nano $\mathrm{MnO}_{2}-\mathrm{ZrO}_{2}$

This might be due to the formation of mixed oxide from metal salts of $\mathrm{Mn}$ and $\mathrm{Zr}$.

The increase in the peak current of the mixed oxide from that of simple oxides and the increase in the peak current due to increase in the metal concentration confirm the increase in the conductivity of the mixed oxide. To temper the cutting edge of electrochemistry, it will be necessary to carry out capacitance measurements, as these are closer to bulk-like techniques.

For a simple parallel plate capacitor, charge on the capacitor, $Q$, is proportional to the voltage drop across the capacitor $V$, and $C$ is the capacitance. Therefore the equation is

$Q=C V$

Capacitance is a crucial factor in electrochemical experiments because it gives rise to current during the charging of the capacitor. To calculate the magnitude of this current, with respect to time $(t)$ and capacitance should be treated as constant recognizing that $\mathrm{d} Q / \mathrm{dt}$ is an expression for current and $\mathrm{d} V / \mathrm{dt}$ is the potential scan rate. The equation is 


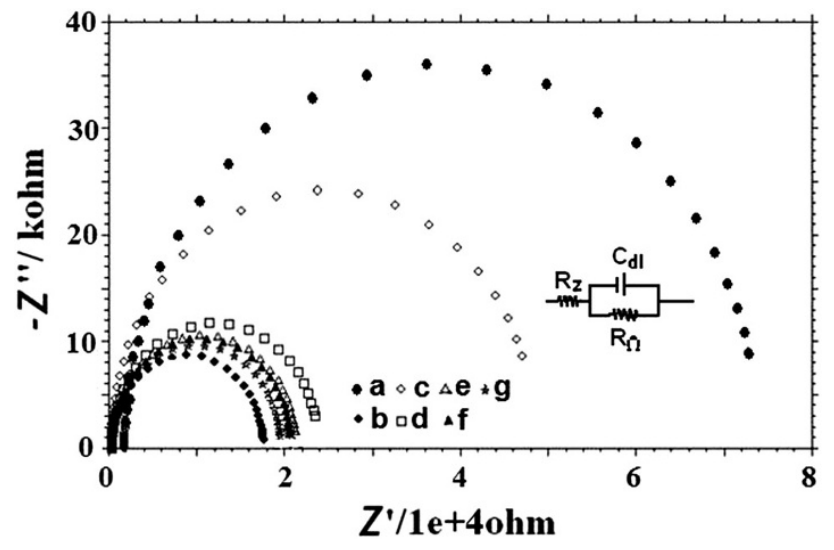

Fig. 12 Electrochemical impedance spectra of (a) nano $\mathrm{MnO}_{2}, \mathrm{~b}$ nano $\mathrm{ZrO}_{2}$, c $0.05 \mathrm{M} \mathrm{MnO}_{2}-\mathrm{ZrO}_{2}$, d $0.15 \mathrm{M} \mathrm{MnO}_{2}-\mathrm{ZrO}_{2}$, e $0.25 \mathrm{M}$ $\mathrm{MnO}_{2}-\mathrm{ZrO}_{2}$, f $0.35 \mathrm{M} \mathrm{MnO}_{2}-\mathrm{ZrO}_{2}$, g $0.45 \mathrm{M} \mathrm{MnO}_{2}-\mathrm{ZrO}_{2}$

$$
\mathrm{d} Q / \mathrm{dT}=C \mathrm{~d} V / \mathrm{dt}
$$

Therefore $i=C \mathrm{v}$

From this very simple derivation, we have an expression for the charging current at the steady state when applying a ramping voltage. If there are no possibilities for electron transfer between the solution and the electrode this is the only current that we will observe. The cyclic voltammogram of mixed oxide shows the influence of various scan rates. The capacitance was calculated from cyclic voltammograms using the above said equation. The calculated values of $\mathrm{MnO}_{2}, \mathrm{ZrO}_{2}$ and $0.05 \mathrm{M} \mathrm{MnO}_{2}-\mathrm{ZrO}_{2}$ mixed oxide are 13,30 and $39 \mu \mathrm{F}$ respectively. The capacitance of chemically synthesized mixed oxide is suggested that, they can well be used as an electronic material.

EIS studies of nano $\mathrm{MnO}_{2}$, nano $\mathrm{ZrO}_{2}$ and $\mathrm{MnO}_{2}-\mathrm{ZrO}_{2}$

Electrochemical impedance measurements were carried out at a frequency range say from 1,000 to $0.01 \mathrm{~Hz}$ at open circuit potential. The simple equivalent Randle circuit for studies is given as an insert in (Fig. 12). The chemically synthesized simple oxide and mixed oxide nanoparticles coated on glassy carbon electrode are used $\left(0.0314 \mathrm{~cm}^{2}\right)$ as working electrode. The cell is composed by a $1.0 \mathrm{~cm}^{2} \mathrm{Pt}$ electrode, $\mathrm{Ag} / \mathrm{AgCl}$ serves as reference electrode. The measurements were made for simple oxides such as nano $\mathrm{MnO}_{2}$, nano $\mathrm{ZrO}_{2}$ (Fig. $12 \mathrm{a}$, b) and nano $\mathrm{MnO}_{2}-\mathrm{ZrO}_{2}$ mixed oxides synthesized at five different concentrations of both $\mathrm{MnSO}_{4}$ and $\mathrm{ZrOCl}_{2}(0.05,0.15,0.25,0.35,0.45 \mathrm{M})$ as shown in Fig. 12c-g. To understand the electrical properties of the electrode/interfaces clearly the Randle's equivalent circuit was chosen to fit the obtained impedance data. In Randle's circuit, it is assumed that the resistance to
Table $3 R_{\mathrm{ct}}$ and $C_{\mathrm{dl}}$ for $0.05-0.45 \mathrm{M} \mathrm{MnO}_{2}-\mathrm{ZrO}_{2}$ mixed oxides

\begin{tabular}{lll}
\hline Concentration of nano $\mathrm{MnO}_{2}-\mathrm{ZrO}_{2} \mathrm{M}$ & $R_{\mathrm{ct}}\left(\Omega \mathrm{cm}^{2}\right)$ & $C_{\mathrm{dl}}\left(\mu \mathrm{F} \mathrm{cm}{ }^{-2}\right)$ \\
\hline 0.05 & 8.393 & 0.0107 \\
0.15 & 2.353 & 0.0769 \\
0.25 & 2.113 & 0.1000 \\
0.35 & 2.053 & 0.1053 \\
0.45 & 1.940 & 0.1205
\end{tabular}

charge transfer $\left(R_{\mathrm{ct}}\right)$ and the diffusion impedance $\left(R_{\mathrm{ct}}\right)$ are parallel to the interfacial capacity $\left(C_{\mathrm{dl}}\right)$. The parallel combination of $R_{\mathrm{ct}}$ and $C_{\mathrm{dl}}$ gives rise to a semicircle in the complex plane plot of $Z^{\prime \prime}$ against $Z^{\prime}$, the semicircle diameter equals charge transfer resistance $\left(R_{\mathrm{ct}}\right)$. This resistance exhibits the electron transfer kinetics of the redox probe at the electrode interface. From the Table 3, it is clear that the decrease in electrical resistivity with the increase in concentration is due to the improvement in crystallite and/or grain size, decrease in defects. This fact confirms the anticorrosive activity of the synthesized nano $\mathrm{MnO}_{2}-\mathrm{ZrO}_{2}$ mixed oxide samples. The lower the concentration of $\mathrm{MnO}_{2}-\mathrm{ZrO}_{2}$ mixed oxide nanoparticles, higher the resistance which is responsible for anti corrosive activity. The small observed variations might be from the nature of electrode conductivities (Chandrasekaran et al. 2008). More resistivity implies a physical adsorption of the corresponding electrodes during the diffusion path way whereas the lower value indicates the good conductivity behavior.

\section{Conclusion}

To summarize, nano $\mathrm{MnO}_{2}, \mathrm{ZrO}_{2}$ and $\mathrm{MnO}_{2}-\mathrm{ZrO}_{2}$ were synthesized by wet chemical method. The characterizations of the chemically synthesized nanoparticles were done using UV-Visible spectroscopic and FTIR studies. The sizes of the synthesized oxides were in the $\mathrm{nm}$ range and they were found to be thermally stable. SEM and TEM studies show a uniform rod-like morphology in the case of mixed oxide. $\mathrm{CV}$ studies revealed that the mixed oxide has good adherent and electrochemical activity on GC and thus it is found to be corrosive protection agent for paints formulation. The capacitance of chemically synthesized mixed oxide was suggested that, they might well be used as an electronic material.

Acknowledgments The authors are extremely grateful to Department of Science and Technology (FAST TRACK and FIST) New Delhi, INDIA for using CHI Electrochemical workstation at V.O.C.College, Tuticorin-8 and Jasco UV-VISIBLE Spectrophotometer. 
Open Access This article is distributed under the terms of the Creative Commons Attribution License which permits any use, distribution, and reproduction in any medium, provided the original author(s) and the source are credited.

\section{References}

Brock SL, Duan NG, Tian ZR, Giraldo O, Zhou H, Suib SL (1998) A review of porous manganese oxide materials. Chem Mater 10:2619-2628

Chandrasekaran R, Soneda Y, Yamashita J, Kodama M, Hatori H (2008) Effect of poly(3,4-ethylenedioxythiophene) (PEDOT) in carbon-based composite electrodes for electrochemical supercapacitors. J Solid State Electrochem 12:1349-1352

Chen Y, Liu C, Li F, Chen H-M (2005) Preparation of single-crystal $\alpha-\mathrm{MnO}_{2}$ nanorods and nanoneedles from aqueous solution. J Alloy Compd 397:282-285

Dietl T, Matsukura H, Cibert F, Ferrand J, Zener D (2000) Model description of ferromagnetism in zinc-blende magnetic semiconductors. Science 287:1019-1022

Dong X, Zhang X, Liu B, Wang H, Li Y, Huang Y, Du Z (2006) Synthesis of manganese oxohydroxide $(\mathrm{MnOOH})$ and $\mathrm{Mn}_{3} \mathrm{O}_{4}$ Nanorods using novel reverse micelles. J Nanosci Nanotechnol 6:818-822

Du F, Liu J, Guo Z, Shape J (2009) Controlled synthesis of CuO and its catalytic application to synthesise amorphous carbon nanofibres. J Mater Res Bull 44:25-29

Feng Q, Kanoh H, Ooi K (1999) Manganese oxide porous crystals. J Mater Chem 9:319-333

Guedes M, Ferreira JMF, Ferro AC (2009) Dispersion of $\mathrm{CuO}$ particles in aqueous suspensions containing 4,5-dihydroxy 1,3benzenedisulphonic acid disodium salt. $\mathrm{J}$ Ceram Int 35:1939-1945

Hosono E, Kudo T, Honma I, Matsuda H, Zhou HS (2009) Synthesis of single crystalline spinel $\mathrm{LiMn}_{2} \mathrm{O}_{4}$ nanowires for a lithium ion battery with high power density. Nano Lett 9:1045-1051
Lu W, Lieber CM (2006) Semiconductor nanowires. J Phys D Appl Phys 39:R387-R406

Luo X-L, Xu J-J, Zhao W, Chen H-Y (2004) Cholesterol biosensor based on MWCNTs- $\mathrm{MnO}_{2}$ Nanoparticle using FFT continuous cyclic voltammetry. Biosens Bioselectron 19:1295-1300

Partha Sarathi V, Thilagavathi G (2011) Synthesis and characterization of zinc oxide nanopartilce and its application on fabrics for microbe resistant defence clothing. Int $\mathrm{J}$ Pharm Pharm Sci 3:392-398

Perez-Maquedaa LA, Matijevicb E (1997) Preparation and characterization of nanosized zirconium (hydrous) oxide particles. J Mater Res 12:3286-3292

Rema Devi BS, Raveendren R, Vaidyan AV (2007) Synthesis and characterization of $\mathrm{Mn}^{2+}$-doped $\mathrm{ZnS}$ nanoparticles. Pramana $\mathbf{J}$ Phys 68:679-687

Shi R, Wang YJ, Li D, Xu J, Zhu YF (2010) Synthesis of $\mathrm{ZnWO}_{4}$ nanorods with [100] orientation and enhanced photocatalytic properties. Appl Catal B Environ 100:173-178

Singh DK, Pandey DK, Yadav RR, Singh D (2012) A study of nanosized zinc oxide and its nanofluid. Pramana J Phys 78:759-766

Subramanian V, Zhu H, Wei B (2008) Nanostructured manganese oxides and their composites with carbon nanotubes as electrode materials for energy storage devices. Pure Appl Chem 80:2327-2343

Wambach J, Baiker A, Wokaun A (1999) $\mathrm{CO}_{2}$ hydrogenation over metal/zirconia catalysts. Phys Chem Chem Phys 1:5071-5080

Wang ZL (2000) Characterizing the structure and properties of individual wire like nano entities. Adv Mater 12:1295-1298

Xia YN, Yang PD, Sun YG, Wu XY, Mayers B, Gates B, Yin YD, Kim F, Yan HQ (2003) One-dimensional nanostructures: synthesis, characterization and applications. Adv Mater 15:353-389

Yang H, Zhu S, Pan N (2004) Studying the mechanisms of titanium dioxide as ultraviolet-blocking additive for films and fabrics by an improved scheme. J Appl Polym Sci 92:3201-3210

Yu KH, Chen JH (2009) Enhancing solar cell efficiencies through 1-D nanostructures. Nanoscale Res Lett 4:1-10 